\title{
Do changes in temperature affect EU Water Framework Directive compliant assessment results of central European streams?
}

\author{
Phillip J. Haubrock ${ }^{1,4^{*}}$ (]) Francesca Pilotto ${ }^{1,2}$ (D) and Peter Haase ${ }^{1,3}$ (D)
}

\begin{abstract}
Background: Benthic invertebrate communities are an integral and longstanding component of stream biomonitoring. However, multiple stressors driven by global change threaten benthic invertebrate communities. In particular, climate warming is expected to disrupt freshwater ecosystems. While an increasing number of studies have shown changes in benthic invertebrate community composition in response to climate warming, the effect on stream assessments has rarely been investigated. As several community composition metrics are also used in stream assessments, we predicted that climate warming would worsen stream assessment results. Therefore, we used a comprehensive data set of 2865 benthic invertebrate samples taken between 2000 and 2014 from small central European low mountain streams. We examined the effects of changes in temperature on common community and stream assessment metrics. We used 31 metrics covering composition, richness, tolerance and function of communities, of which many are used in various stream assessment schemes.

Results: Against our expectations, we identified a decreasing air temperature trend of $-0.18^{\circ} \mathrm{C}$ over 15 years. This trend was accompanied by significant changes in community composition, for example, increases in species richness and decreases in the community temperature index (CTI). Further, we identified slight concomitant improvements of various globally used stream quality assessment metrics, such as a decreasing saprobic index and an increasing BMWP.

Conclusions: While temperature increased by $+0.9^{\circ} \mathrm{C}$ during the past 30 years (1985-2014), our 15-year study period (2000-2014) showed a decrease by $-0.18^{\circ} \mathrm{C}$. Therefore, we regard the concomitant improvement in several assessment metrics as a recovery from prior increasing temperatures. In turn, we assume that increases in water temperature will lead to opposite effects and therefore cause declining assessment results. Water managers should be aware of this linkage that in turn could provide a chance to mitigate the effects of global warming by, for example, planting trees along the rivers and the removal of artificial barriers to increase current velocity to minimize a warming effect.
\end{abstract}

Keywords: Climate change, Stream quality, Assessment, Freshwater invertebrates, Macroinvertebrates, Community composition

*Correspondence: phillip.haubrock@senckenberg.de

${ }^{1}$ Department of River Ecology and Conservation, Senckenberg Research Institute and Natural History Museum Frankfurt, Clamecystrasse 12, 63571 Gelnhausen, Germany

Full list of author information is available at the end of the article

\section{Background}

Climate warming is affecting biodiversity at an unprecedented rate $[7,48]$. In recent decades, accelerated warming rates have resulted in changes in terrestrial [20,21] and freshwater community compositions [55], as well as species range shifts towards higher elevated areas and towards the poles [62, 73]. Climate warming will 
particularly threaten taxa that are associated with colder water temperatures, such as several stream benthic invertebrates constituting a large part of climate sensitive taxa (i.e. EPT-taxa [Ephemeroptera, Plecoptera and Trichoptera]; [23]). In contrast, warm dwelling and less specialized taxa will potentially increase due to an increase in suitable habitats [16]. For benthic stream invertebrate communities, such spatial and temporal community shifts to meet their species-specific temperature preferences have been described [32] and will likely continue in the future [23]. This is especially true for (low) mountain streams, which are considered biological hotspots as they serve as refugia for cold-adapted and specialized species [39], and are disproportionally affected by temperature changes [62].

Beside such direct temperature effects, there are many indirect effects resulting from climate warming. For example, increasing water temperatures lower solved oxygen concentrations [8], which in turn affect most stream benthic invertebrate species as most of them hold species-specific preferences towards certain oxygen levels. However, reduced oxygen concentrations are also caused by organic pollution. Pollution effects on benthic invertebrates are well studied [9]. In the saprobic system, a large number of benthic invertebrate taxa have an assigned saprobic value, indicating their tolerance towards organic pollution. As oxygen is consumed during the dismantling of organic substance, the saprobic system is in an inverse relation to a waterbody's oxygen concentration [59]. Accordingly, the effect of climate warming driven decreases in oxygen concentration on stream benthic invertebrates should be similar to those caused by organic pollution. Hence, the saprobic system and or other related metrics might also be affected by climate warming.

Further indirect effects of climate warming are changes in the solubility of chemicals. Higher temperatures increase the solubility of most chemicals leading to higher concentrations in the water [1], eventually affecting sensitive taxa. Higher temperatures also promote primary production (i.e., algae growth, increased biofilm; [43] causing various changes in the food web of the respective communities. The latter are well reflected in changes in functional feeding groups (aside from other trait based metrics such as body size, respiratory apparatus, etc.) of benthic invertebrate communities that could easily be measured by investigating the relative share of the feeding types present in the community under study.

In summary, changes in temperature can affect benthic invertebrates directly, yet indirect effects may be more pervasive through alterations to chemical and physical properties of freshwater ecosystems. The resulting changes in benthic invertebrate community composition can be mainly driven by changes in (a) species richness, (b) species abundance, (c) loss of sensitive (indicator) species and (d) changes of the trophic system. Metrics describing such changes in community composition using benthic invertebrates have a long history in stream quality assessments [36]. Indeed, a broad variety of stream assessment schemes are applied globally (e.g., RIVPACS in UK; MEDPACS in Spain; PERLA in the Czech Republic; SWEDACRI in Sweden; AUSRIVAS in Australia; [28]), reflecting high biogeographic variability and different stream assessment histories [9]. Some of the stream quality-associated metrics used in the different assessment methods are based on the communities' species composition alone, while others are calculated on the basis of species-specific requirements.

With the use of such stream quality assessment schemes, potentially occurring changes can be measured using a broad set of metrics reflecting four major metric groups: (1) 'composition and abundance', (2) 'richness and diversity', (3) 'tolerance and sensitivity' and (4) 'functional feeding groups' [36]. Exemplary, individual metrics such as the Saprobic Index or the Biological Monitoring Working Party Score are frequently used in different national stream quality assessment schemes (e.g., PERLODES; RIVPACS, etc.). Other metrics that are used in stream assessments can be seen as direct proxies of community compositions (e.g., percentage of Ephemeroptera, Plecoptera and Trichoptera-EPT\%; Number of Taxa; Number of Families; $[37,40])$. All of these metrics that are used to assess the ecological status of a river might, however, be potentially subject to temperature effects as they are generally estimated on the basis of presences and abundances of living organisms such as benthic invertebrates. Owing to the pervasive effects of human-mediated stressors such as climatic warming [15], results from metrics utilized by various stream quality assessment schemes have likely been affected by climatic change [40]. In turn, identifying such a link between climate warming and stream quality assessment results may have significant implications for nationally and globally used assessment systems.

Against this background, we hypothesize that changes in air temperature (as a common proxy for water temperature) will trigger changes in community composition which consequently affect stream assessment results, as most assessment systems are based on common community metrics that are also sensitive towards temperature. In particular, we hypothesize that increasing temperatures will result in lower stream assessment results (i.e., lower metric scores), while periods of cooling will result in higher stream assessment results. To test our hypothesis, we analyzed a large dataset comprising 2865 benthic invertebrate samples from central european low 
mountain streams sampled over a period of 15 years (2000-2014).

\section{Results}

In contrast to the overall increase in temperature in the past decades in Germany, and against our expectations, our study period was characterized by a decrease in mean annual air temperature of $-0.18{ }^{\circ} \mathrm{C}$ $\left(-0.012 \pm 0.004{ }^{\circ} \mathrm{C}\right.$ year ${ }^{-1}$; LME: $p<0.05$; Additional file 1). Comparably, the minimum temperature decreased by $-0.16{ }^{\circ} \mathrm{C}\left(-0.011 \pm 0.004{ }^{\circ} \mathrm{C}\right.$ year ${ }^{-1}$; LME: $\left.p>0.05\right)$, while the maximum temperature decreased by $-0.19^{\circ} \mathrm{C}$ $\left(-0.013 \pm 0.004{ }^{\circ} \mathrm{C}\right.$ year ${ }^{-1}$; LME: $p<0.05$; Additional file 3: Table S1). The calculated community temperature index $(\mathrm{CTI})$ for the same time period decreased by $-0.44{ }^{\circ} \mathrm{C} \quad\left(-0.029{ }^{\circ} \mathrm{C} \pm 0.005^{\circ} \mathrm{C}\right.$ year ${ }^{-1}$; LME: $p<0.05$; Table 1). In respect to stream quality metrics, the SI displayed a decrease of $-3.0 \%\left(-0.002 \pm 0.001\right.$ year $^{-1}$, GLMM: $p<0.05)$, while the MMI $(29.3 \%$; $0.019 \pm 0.004$ year $^{-1}$; GLMM: $\left.p<0.05\right)$, BMWP score $\left(19.8 \%\right.$; $1.3 \pm 0.05$ year $^{-1}$; GLMM: $\left.p<0.05\right)$ and Number of taxa (23.0\%; 0.016 \pm 0.25 year $^{-1}$; GLMM: $p<0.05$ ) increased significantly (Fig. 1; Table 1). Furthermore, the percentage of EPT-taxa indicated a slight increase (ЕPT\%: 4.4\%; $0.293 \pm 0.003$ year $^{-1}$; GLMM: $p>0.05$ ). All these assessment metrics indicated an increase in stream quality.

The analyzed precipitation data showed a decrease in precipitation and, thus, diminished dilution over the study period (Additional file 2). Similarly, changes in land use from 2000 to 2012 indicated no amelioration (Additional file 3), underlined by the land-use index (LUI; [10]), suggesting a slight increase from 109.2 to 111.0.

While the rates of change for mean annual air temperature, CTI, and Number of taxa did not vary significantly from each other (indicated by the overlap of the $95 \%$ confidence interval), the slope of the SI was identified as significantly different from all other slopes except for the MMI and EPT \% (Fig. 1h). Furthermore, the MMI 95\% confidence interval overlapped with the temperature, while the slope of the BMWP score did not overlap with any other metric. Subsequent to quality metrics, several community composition metrics computed on the basis of species abundances were identified to significantly vary over the study period (Table 1), especially functional group and composition metrics, indicating profound changes within the communities.

Within the compositional metrics, we observed that "Trichoptera-\%" with 16.6\%, "Ephemeroptera-\%" with $-26.4 \%$ and "Diptera-\%" with $-15.1 \%$ mostly directed the ongoing transition within the community composition (GLMM: $p<0.05$; Fig. 2). In respect to functional groups, significant decreases in "Grazers and Scrapers-\%"
$(-19.9 \%$; GLMM: $p<0.05)$ and "Passive Filter Feeders-\%" (- 52.6\%; GLMM: $p<0.05)$, and significant increases in "Active Filter Feeders- \%" (21.2\%; GLMM: $p<0.05)$ and "Shredders-\%" (40.9\%; GLMM: $p<0.05)$ dominated observed changes in the community composition (Fig. 2).

\section{Discussion}

Even though (and against our expectation) temperature decreased during the study period (2000-2014), we observed significant changes in community composition, as indicated by changes in various metrics. Whilst effects of changes in temperature on benthic invertebrate communities have been reported in the past [34], none have yet examined the implications of climate change for common biomonitoring metrics, despite their importance for water quality assessments. Jyväsjärvi and Hämäläinen [42] demonstrated that while benthic invertebrate community responded rapidly to short-term but large-scale climate fluctuations, gradual changes in temperature can cause strong variance in community composition [14]. Apart from the overall global increase in temperature, the frequency of cooling periods and reoccurring "short-term" temperature fluctuations are reflected in considerable changes in communities [71]. However, the observation of such a "cooling period" strongly depends on the temporal window that is investigated $[29,26]$. In our study, the 15 years of observation are embedded in a longer period of time that is actually showing an increase in temperature of $\sim+0.9{ }^{\circ} \mathrm{C}$. Nevertheless, longer periods of decreasing temperatures have not yet been investigated for their effect on aquatic invertebrate communities.

\section{Temperature-driven changes in community composition and functionality}

The Water Framework Directive has been a milestone for the monitoring and quality assessment of European streams and rivers [69]. Some of the utilized assessment metrics have been proven adequate for the purpose of identifying specific stressors [52]. To our knowledge, however, there is currently no assessment metric that is assessing temperature effects on stream benthic invertebrates, although temperature is a considerably important stressor affecting stream communities. Due to the so far largely unexplored interactions of assessment metrics, it is currently difficult to distinguish between a, for example, pollution signal and a temperature signal as (e.g.) the saprobic index also responds to changes in temperature.

Here, we showed significant changes in 10 out of 13 'composition and abundance metrics', indicating a direct connection between changes in the abundance of certain taxa and temperature. This is particularly noteworthy, 
Table 1 Changes in estimated community metrics over the study period (2000-2014); metrics highlighted as "italic" were identified to significantly change over time

\begin{tabular}{|c|c|c|c|c|c|c|c|c|}
\hline Metric family & Full name & Short name & Estimate & $\begin{array}{l}\text { Respective } \\
\text { increase } \\
\text { or decrease }\end{array}$ & Std. Error & $\mathrm{z}$ value & $p$ & $R^{2} / \mathrm{CR}^{2}$ \\
\hline Air Temperature & & AirT & 0.01493 & $-0.18^{\circ} \mathrm{C}$ & 0.004008 & -3.725 & $<0.001$ & $0.29 / 0.48$ \\
\hline \multirow[t]{13}{*}{$\begin{array}{c}\text { Composition/ } \\
\text { Abundance }\end{array}$} & $\begin{array}{l}\text { Total Abun- } \\
\text { dance }\end{array}$ & TAbund & $3.21 e-02$ & $48.9 \%$ & $4.592 e-03$ & 6.981 & $<0.001$ & $0.09 / 0.99$ \\
\hline & ЕРТСВО \% & ЕРТСВО \% & $2.75 e-02$ & $39.3 \%$ & $2.572 e-03$ & 10.040 & $<0.001$ & $0.01 / 0.04$ \\
\hline & EPT \% & EPT_perc \% & $2.89 e-03$ & $4.34 \%$ & $1.222 \mathrm{e}-02$ & 0.238 & 0.812 & $0.04 / 0.25$ \\
\hline & $\begin{array}{l}\text { Ephemerop- } \\
\text { tera \% }\end{array}$ & E\%_perc & -0.018 & $-26.4 \%$ & $6.472 e-3$ & -2.747 & 0.006 & $0.01 / 0.01$ \\
\hline & Plecoptera \% & P\%_perc & $1.82 e-02$ & $27.5 \%$ & $9.688 e-03$ & 1.877 & $<0.001$ & $0.13 / 0.43$ \\
\hline & Trichoptera \% & T\%_perc & $1.31 e-02$ & $16.6 \%$ & $5.773 e--03$ & 1.902 & $<0.030$ & $0.02 / 0.18$ \\
\hline & Coleoptera \% & Col \%_perc & 0.002 & $2.3 \%$ & 0.007 & -0.205 & 0.837 & $0.01 / 0.22$ \\
\hline & Bivalvia \% & Biv \%_perc & $4.635 e-03$ & $6.9 \%$ & $1.850 \mathrm{e}-02$ & -0.251 & 0.802 & $0.12 / 0.66$ \\
\hline & Odonata \% & Odo \%_perc & $5.41 e-02$ & $83.4 \%$ & $3.067 e-02$ & 1.764 & 0.178 & $0.18 / 0.62$ \\
\hline & Hirudinea \% & Hir \%_perc & $-4.60 e-02$ & $-60.8 \%$ & $1.311 e-02$ & -6.876 & $<0.001$ & $0.12 / 0.42$ \\
\hline & Gastropoda \% & Gas \%_perc & $-2.520 e-02$ & $-37.3 \%$ & $1.212 e-02$ & -2.079 & $<0.05$ & $0.03 / 0.45$ \\
\hline & Diptera \% & Dip \%_perc & $-0.0,101,269$ & $-15.1 \%$ & 0.005 & -1.878 & $<0.05$ & $0.01 / 0.27$ \\
\hline & Crustacea \% & Crust \% & $1.159 e-02$ & $17.5 \%$ & $9.329 e-03$ & 1.242 & 0.214 & $0.13 / 0.55$ \\
\hline \multirow{6}{*}{$\begin{array}{l}\text { Richenss/Diver- } \\
\text { sity }\end{array}$} & Number of Taxa & Num_Tax & $1.52 e-02$ & $22.989 \%$ & $1.426 e-03$ & 10.665 & $<0.001$ & $0.10 / 0.69$ \\
\hline & $\begin{array}{l}\text { Number of } \\
\text { Families }\end{array}$ & Num_Fam & $1.153 e-02$ & $17.395 \%$ & $1.266 e-03$ & 9.113 & $<0.001$ & $0.08 / 0.30$ \\
\hline & $\begin{array}{l}\text { Shannon Diver- } \\
\text { sity Index }\end{array}$ & Shan & $8.747 e-04$ & $1.312 \%$ & $3.677 e-03$ & 0.238 & 0.812 & $0.00 / 0.00$ \\
\hline & $\begin{array}{l}\text { Simpson Diver- } \\
\text { sity Index }\end{array}$ & Simpson & $1.953 \mathrm{e}-04$ & $0.293 \%$ & $6.016 \mathrm{e}-03$ & 0.032 & 0.974 & $0.00 / 0.00$ \\
\hline & $\begin{array}{l}\text { Margalef rich- } \\
\text { ness }\end{array}$ & Margalef & $1.232 e-02$ & $18.594 \%$ & $2.405 e-03$ & 5.121 & $<0.001$ & $0.04 / 0.04$ \\
\hline & Evenness & Evenness & $-8.073 e-04$ & $-1.211 \%$ & $6.171 e-03$ & -0.131 & 0.896 & $0.00 / 0.00$ \\
\hline \multirow[t]{6}{*}{$\begin{array}{l}\text { Tolerance/Sensi } \\
\text { tivity }\end{array}$} & $\begin{array}{l}\text { i-German Sapro- } \\
\text { bic Index }\end{array}$ & GSI & $-2.000 e-03$ & $-3.00 \%$ & $4.060 e-04$ & -4.925 & $<0.001$ & $0.26 / 0.89$ \\
\hline & $\begin{array}{l}\text { Saprobic } \\
\text { Index- } \\
\text { Zelinka and } \\
\text { Marvan }\end{array}$ & SI_ZM & $-2.763 e-03$ & $-2.912 \%$ & $1.358 e-03$ & 9.626 & $<0.001$ & $0.01 / 0.01$ \\
\hline & $\begin{array}{l}\text { Biological } \\
\text { monitoring } \\
\text { working party } \\
\text { Score }\end{array}$ & BMWP Score & $1.308 e-02$ & $19.749 \%$ & $1.358 e-03$ & 9.631 & $<0.001$ & $0.12 / 0.92$ \\
\hline & $\begin{array}{l}\text { Average Score } \\
\text { per Taxon }\end{array}$ & ASPT & $3.329 e-03$ & $4.289 \%$ & $2.345 e-03$ & 1.217 & 0.224 & $0.01 / 0.01$ \\
\hline & $\begin{array}{l}\text { Index of } \\
\text { biocoenotic } \\
\text { region }\end{array}$ & $\mathrm{IBCR}$ & $4.142 \mathrm{e}-04$ & $0.621 \%$ & $2.833 e-03$ & 0.146 & 0.884 & $0.01 / 0.01$ \\
\hline & $\begin{array}{l}\text { Abundance } \\
\text { weighted } \\
\text { Community } \\
\text { Temperature } \\
\text { Index }\end{array}$ & $\mathrm{CTI}_{\mathrm{ab}}$ & -0.030 & $-0.44^{\circ} \mathrm{C}$ & 0.005 & -6.187 & $<0.001$ & $3.95 e-06 / 2.42 e-05$ \\
\hline
\end{tabular}


Table 1 (continued)

\begin{tabular}{|c|c|c|c|c|c|c|c|c|}
\hline Metric family & Full name & Short name & Estimate & $\begin{array}{l}\text { Respective } \\
\text { increase } \\
\text { or decrease }\end{array}$ & Std. Error & $z$ value & $p$ & $R^{2} / \mathrm{cR}^{2}$ \\
\hline \multirow[t]{6}{*}{$\begin{array}{l}\text { Functional } \\
\text { group per- } \\
\text { centage }\end{array}$} & $\begin{array}{l}\text { Percentage of } \\
\text { active filter } \\
\text { feeder }\end{array}$ & ActFilFeed \% & $11.404 e-02$ & $27.2 \%$ & $6.671 e-03$ & 2.105 & $<0.05$ & $0.03 / 0.17$ \\
\hline & $\begin{array}{l}\text { Percentage of } \\
\text { passive filter } \\
\text { feeder }\end{array}$ & PasFilFeed \% & $-3.571 e-02$ & $-52.6 \%$ & $7.367 e-03$ & -4.847 & $<0.001$ & $0.01 / 0.26$ \\
\hline & $\begin{array}{l}\text { Percentage of } \\
\text { gatherers and } \\
\text { collectors }\end{array}$ & GathCol \% & $4.074 \mathrm{e}-03$ & $6.1 \%$ & $1.705 \mathrm{e}-0$ & 0.239 & 0.811 & $0.00 / 0.03$ \\
\hline & $\begin{array}{l}\text { Percentage of } \\
\text { grazers and } \\
\text { scrapers }\end{array}$ & GrazScra \% & $-1.336 e-02$ & $-19.9 \%$ & $2.978 e-03$ & -4.487 & $<0.001$ & $0.01 / 0.06$ \\
\hline & $\begin{array}{l}\text { Percentage of } \\
\text { predators }\end{array}$ & Pred $\%$ & 0.002 & $3.5 \%$ & 0.004 & 0.657 & $<0.001$ & $0.01 / 0.04$ \\
\hline & $\begin{array}{l}\text { Percentage of } \\
\text { shredders }\end{array}$ & Shred \% & $2.690 e-02$ & $40.9 \%$ & $4.999 e-03$ & 5.380 & $<0.001$ & $0.01 / 0.18$ \\
\hline Others & $\begin{array}{l}\text { Multimetric } \\
\text { Index }\end{array}$ & $\mathrm{MMI}$ & 0.019 & $29.3 \%$ & 0.012 & 1.569 & $<0.001$ & $0.26 / 0.88$ \\
\hline
\end{tabular}

as some taxa prefer cold water streams [68, 45] while exhibiting minor plasticity [4] and thus, being in alignment with recent literature signaling opposite trends for scenarios with increasing temperatures [19]. Similar to our identified changes in 'composition and abundance metrics', we identified 5 'functional groups' metrics to significantly change over time. Specifically, we identified an increase in all functional groups except "Passive Filter Feeders" and "Grazers and Scrapers", as both groups potentially suffer from a decrease in productivity due to cooler temperatures in the water [74].

Our observed changes in metrics reflect directly opposing trends for benthic invertebrates than identified by $[22,23]$ for a temperature increase in European streams. Especially the observed increases in 'community and abundance' metrics can be interpreted as being driven by decreasing temperatures, further indicating a potential for recovery of the stream communities [57]. Reciprocally, an upward trend in temperature would likely lead to changing community compositions as well as changes in certain taxa (e.g., a decrease in Plecoptera and increase in Chironomidae; [32]) and feeding groups opposite to what was indicated for decreasing temperatures [70].

Temperature-driven changes in stream assessment results We observed a slight increase in stream quality which is indicated by, for example, an increasing saprobic index and BMWP score over the studied time period. On that note, we further extend on the hitherto less investigated existence of a linkage between temperature-driven changes in quality assessment results. Based on the identified changes in temperature, the observed ameliorating trend could be due to: (1) a shift in 'composition and abundance' metrics, i.e., a shift from warm-dwellers to cold-dwellers, or; (2) a temperature-driven change in 'sensitivity and tolerance metrics' through a recovery of indicator species [24]. Furthermore, we were able to identify varying levels of sensitivity among stream assessment metrics regarding temperature-linked changes in community composition. The BMWP score indicated a rather strong, more sensitive reaction to changing temperatures; while, metrics such as the saprobic index or percentage of EPT-taxa expressed a less sensitive response. Such differing signals can be linked to the taxa used in each respective metric, of which some are more strongly affected by temperature variations than others [22]. Furthermore, the differing response might also relate to the BMWP score using the tolerance of taxa towards pollution at a higher taxonomical level (family). The BMWP, thus, considers not only a broader variability but also lower resolution in the utilized species compared to, e.g., EPT-taxa and SI, which both use certain taxa at the species/genus level and, thus, may be more restrictive [53]. Accordingly, the German SI relies on species information which are not considered in the estimation of the familylevel based BMWP score as it is commonly used in other countries (e.g., UK). This likely makes it less sensitive to visible changes. As such, the BMWP and its resonance 

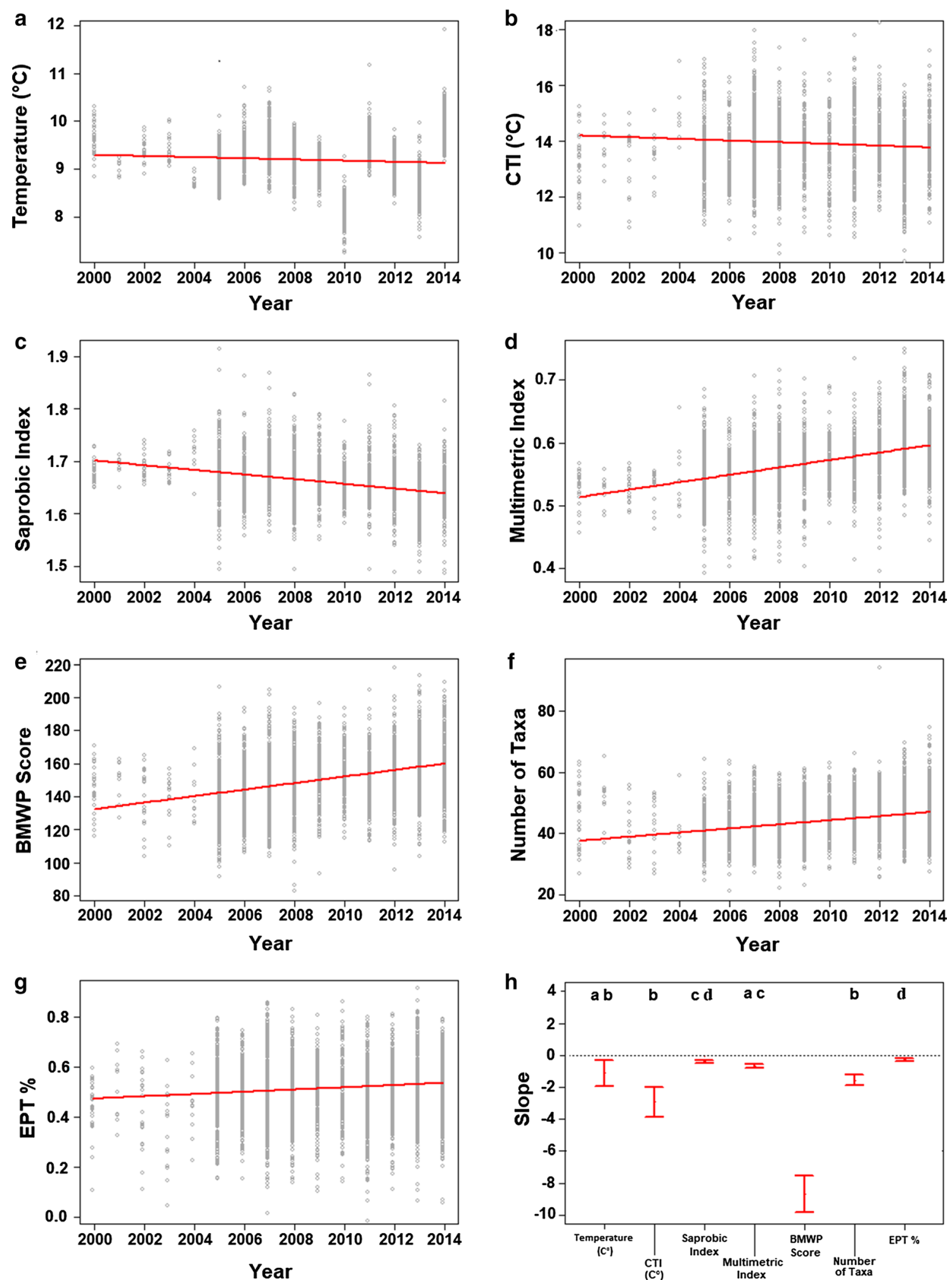

Fig. 1 Changes in (a) mean annual air temperature $\left[{ }^{\circ} \mathrm{C}\right],(\mathbf{b}) \mathrm{CTI}\left[{ }^{\circ} \mathrm{C}\right]$, (c) Saprobic Index $[\mathrm{SI}]$, (d) Multimetric Index $[\mathrm{MMI}]$, (e) BMWP Score, (f) Number of Taxa, (g) percentage of EPT-taxa [EPT \%] during the study period 2000-2014. Plots are of type "conditional"; thus, all covariates were held constant to their median values. (h) Slopes $( \pm 95 \% \mathrm{Cl})$ of the relationships between response variables $(\mathbf{a}-\mathbf{g})$ and time. All slopes were significantly different from zero $(p<0.05)$. The slopes of MMI, BMWP Score, Number of Taxa and EPT \% were inverted (they were strictly positive) because here we want to compare the rate of change, independent from the direction of change. 


\section{a}

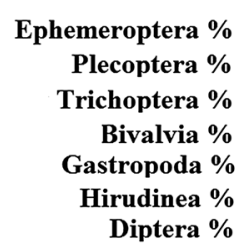

b

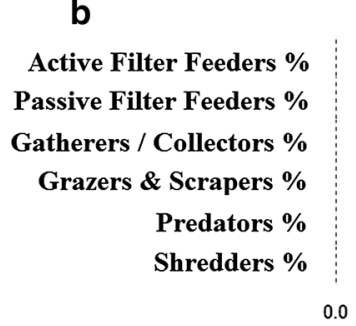

0.0

\section{.}$$
\text { . }
$$

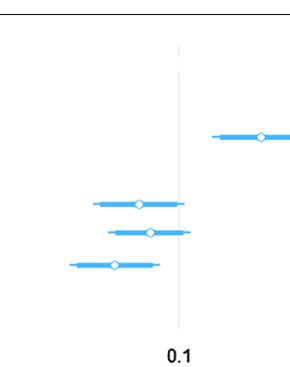

(1)

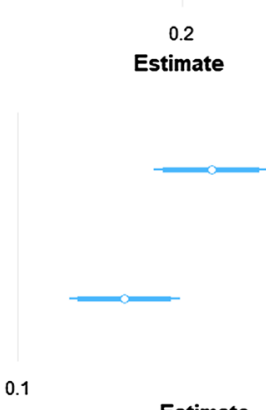

Estimate

Fig. 2 a Effect sizes of individual composition metrics [\%] on changes in the total abundance of the community. Effect sizes are expressed as standardized beta coefficients $( \pm 95 \% \mathrm{Cl}$ ) resulting from generalized linear mixed models. b Effect sizes of individual functional groups [\%] on changes in the total abundance of the community. Effect sizes are expressed as standardized beta coefficients ( $\pm 95 \% \mathrm{Cl}$ ) resulting from generalized linear mixed models

to community changes can be seen as an early indicator, while SI and other metrics may react with a certain time lag towards changes in temperature.

A point that should be raised is whether changes in stream quality as described in the past [50], that were substantially based on changes in benthic invertebrate communities, are ultimately and entirely due to changes in pollution, improvements or deterioration in water quality. Observed changes may to some degree be linked to changes in climate (or interactions with other stressors like changes in precipitation driven dilution of pollutants). However, an identified correlation does not naturally imply causality [66]. In this work, despite having identified a decreasing trend in temperature, we cannot exclude the possibility that other stressors had no effect at all. However, the filter criteria that we applied to our dataset should have further minimized the importance of other stressors. The German Federal Agency for Environment ('Umweltbundesamt') highlighted that the ecological state of $91.8 \%$ freshwater systems was not appraisable as "good" and ground water quality did not improve between 2009 and 2015. Ultimately, chemical stress is considered as high [11]. Similarly, the studied period was not characterized by increased precipitation (Additional file 2), submersible contributing to an increased dilution, nor an ameliorating trend in land use (Additional file 3). For these reasons, we argue that an effect of decreasing pollution as a factor related to changes in community or stream quality associated metrics can be neglected. It can further be assumed that the strong connections between temperature and community composition as well as consistent correlation between temperature and stream quality associated metrics will persist if temperatures further increase [25, 72]. According to the recent climate projections [51], it can additionally be assumed that such increasing temperatures will have profoundly deteriorating effects on community assemblages [32, 64] and, therefore, also associated assessment results.

\section{Potential implication and mitigation measures}

The existence of a potential linkage between community composition, stream assessment, and temperature, going into both directions, will ultimately have to be considered in management and restoration projects $[13,41]$ as it raises the hope that timely actions on climate change effects could effectively reverse previous changes in stream communities. Recently, it was argued that community changes can be accompanied by a temporal debt due to abiotic stress [72]. This debt was argued to originate from an assumable inaccuracy due to the specificity of a species' temperature tolerance and the potential existence of other stressors [58]. Accordingly, Vaughan and Gotelli [72] showed the effectiveness of mitigation efforts through a reduction in pollution, implying the imminent need to increase restoration efforts. Further, efforts and approaches that aim at combating climate change effects and habitat destruction, thus lowering 
their respective impacts on aquatic invertebrate communities, exist. For instance, a recovery of riparian and stream bank vegetation (i.e., by trees providing shade) lowered temperature effects on small sized streams, being beneficial for benthic invertebrate taxa with sensitive thermal tolerances [60]. This effect could be transferred to even medium-sized streams where, depending on the locality, larger trees could serve as an overshadowing canopy. In the course of the energy transition, a reduced outflow of waste heat into rivers by power plants could have a similar, but potentially local effect on benthic invertebrate communities. Adding to this, a removal of barriers could increase current velocity, leading to lower temperatures. Lastly, the increased presence of buffer strips constituted by riparian vegetation might reduce the entry of pollutants and nutrients from, e.g., land use in direct proximity to the water body.

\section{Conclusions}

To accurately assess stressors that affect the quality of freshwater ecosystems, ideally assessment metrics display specifically the effect of the respective stressor. However, we have shown that various assessment metrics suggest to also respond to a temperature signal and, thus, may be affected by climate change. Increasing temperature could lead to a decrease in water quality. In certain cases, managers could be pressured to decrease pollution, albeit temperature being the key driver. However, as pollution and temperature interact, the sensitivity of streams to pollution will increase with increasing temperature. Accordingly, pollution reductions need to be more stringent in a warmer climate, implicating that managers might need to reduce pollution even if temperature is the key driver. Hence, it would be advisable to advance the currently used assessment system with all its currently used metrics to consider the connection between stressors, temperature and metrics. This could be done by, e.g., refining these currently used metrics to not incorporate a temperature signal, or to develop new metrics which explicitly displays the latter, thus enabling managers to filter out the effect of temperature and better understand the effect of specific stressors.

\section{Materials and methods \\ Biotic data}

We compiled a total of 7386 stream benthic invertebrate samples from low mountain streams in Germany that were sampled between 2000 and 2014. We chose low mountain streams, as they are generally subjected to a considerable variation in elevation, therefore allowing a restructuring of stream communities over rather short distances to meet temperature requirements [32]. These samples originated from annually conducted field surveys as part of the European Water Framework Directive (WFD) monitoring of the German states. Samples were collected following the German EU WFD compliant sampling method described by Haase et al. [30], in which each sample comprises 20 subsamples corresponding to a total of $1.25 \mathrm{~m}^{2}$ of the stream bed, proportionally corresponding to the coverage of major habitats within the site.

To ensure homogeneity and to limit the effect of other stressors than temperature [72], we filtered the entire dataset by applying six criteria: (1) all taxa were identified to the level proposed by the German EU WFD compliant "Operational Taxalist" (mostly to species and genus levels, subfamily or family levels for Chironomidae and Oligochaeta) to ensure comparable taxonomic resolution [31]; (2) taxa that were only sampled once were deleted to avoid the confounding effects from taxa that were not established in the study area; (3) only samples from small low mountain streams in Central European highlands (German stream type 5: small siliceous low mountain streams; [56]) were selected to eliminate potential effects of different stream types; (4) only samples collected between March and May of the prospective year were used to exclude confounding effects driven by seasonality; (5) samples with species richness in the lower 10th percentile of all of the samples were excluded from the analysis $(<21$ taxa per sample), given such samples are not suitable for examining the effects of temperature due to the low species richness, potentially reflecting heavy human disturbance; (6) we ensured, that a minimum number of ten sites were available for each sampling year to provide a comparable sample size among years [32]. As a result, a total of 2869 samples for the period 2000-2014 located between 16 and $1013 \mathrm{~m}$ a.s.l., latitude of $49.36^{\circ}-52.51^{\circ}$ and longitude of $6.35^{\circ}-14.36^{\circ}$ remained (Additional file 4).

\section{Climatic data}

Climatic data for the studied time period were extracted from the E-OBS gridded dataset developed by the European Climate Assessment and Database (ECA\&D, www. ecad.eu; [18] which is maintained by the Copernicus Climate Change Service (http://surfobs.climate.copernicus .eu/). The E-OBS is an observational and gridded dataset and includes data on modeled air temperature data covering the period 01.01.1950-31.12.2018 with a high resolutional accuracy of $0.1^{\circ}$. Locality-specific temperature data were extracted from the database using reference coordinates and date of sampling from each biotic measurement. With these data, the annual mean and minimum (consisting of the mean temperature from the months December, January and February) temperature from the year of the sampling as well as the maximum 
(consisting of the mean temperature from the months June, July and August) temperature of the year prior to sampling were estimated for each site and year [40]. Air temperature was used as a proxy for water temperature $[33,34]$ due to the lack of water temperature measurements with adequate and comparably high temporal and spatial resolution and the strong linear relationship with stream temperature $[3,17,38]$. We further collected data on annual precipitation from the German Meteorological Service (www.dwd.de) and openly available information on land use changes from 2000 and 2012 using the CORINE land use dataset from the metadata catalog of the Federal Environment Agency (www.gis.uba.de). With these data, we investigate if (i) a change in precipitation could have induced a change in dilution, and (ii) if a potential land use change may have affected the catchment area and thus, sampled streams.

\section{Changes in community composition, functional groups and stream assessment}

We selected a comprehensive list of metrics belonging to the four major metric groups 'composition and abundance,' 'richness and diversity', 'tolerance and sensitivity', and 'functional groups' (see Table 2). Several of these metrics are actively used in stream assessments [37]. Additionally, we computed two further assessment metrics. First, the Multi-Metric Index (MMI) as the German national metric, describing the general degradation of a site. It is the weighted mean of four stream type-specific metrics (Type 5 streams: Fauna-Index, describing benthic invertebrate communities on the basis of stream type-specific indicator species; EPT \%; Rheo-Index, ratio of rheophilic and rheobionic taxa of a stream to species found in standing water bodies and ubiquists; percentage of hyporhithral colonizers, individuals preferring to live in the hyporhithral area; [49]). This weighted mean is scaled to values between zero (poor quality) and one (high quality) according to specific reference conditions [44]. Second, the German Saprobic Index (SI) as an assessment index was used to evaluate organic pollution via the estimated oxygen demand of benthic invertebrate species [61] and a common determinant of the biological water quality on the basis of listed indicator species and their abundances within a sample. Estimated SI values rank between 0.0 and 4.0, with the latter being considered as a bad ecological state. All metrics were computed using the ASTERICS software (http://www.fliessgewa esserbewertung.de/download/berechnung/).

To provide further evidence that temperature changes correlate with community changes, the abundance weighted CTI was calculated on the basis of the stream zonation concept (seven stream zones; eucrenal, hypocrenal, epirhithral, metarhithral, hyporhithral, epipotamal and metapotamal) following Haase et al. [32]. In this concept, each zone is characterized by specific abiotic features and a probability for most European invertebrate taxa to occur in them according to its taxon-specific temperature preference [63]. Hence, the usage of an abundance weighted CTI reflects temperature-driven changes in benthic invertebrate communities.

Spatial as well as temporal patterns of CTI and temperatures were investigated with linear mixed effect models (LMEs) using the R package "nlme" [54]. Changes in community metrics were explored with generalized linear mixed models (GLMMs) using the R package "lme4", utilizing Poisson distributions for count data and Binomial distributions for percentage data [6]. The respective response variables were analyzed as a function of spatial and temporal variables (year, elevation, latitude, longitude, temperature). Hence, each model consisted of the specific response variable and the explanatory variables 'year', 'latitude', 'longitude', 'elevation,' 'minTemp', 'maxTemp', and 'AnnualMeanTemp' as explanatory variables. We initiated all models with all explanatory variables and compared all combinations of these predictor variables as well as their respective absence for each model using Akaike information criterion (AIC) to determine which variables were important predictors. Site (accounting repeated measurements) and the variable "observation" (i.e., as a vector from 1 to the total number of observations) were included to account for over-dispersion and repeated measures within sites over time [27]. All predictors were checked for variance inflations to be lower than four to exclude the possibility of collinearity. To analyze spatial and temporal patterns for quality associated metrics (MMI, SI, BMWP Score, Number of Taxa, and percentage of EPT-taxa), additional GLMMs were employed. We also included The respective weighting factors (higher weight to values with lower variance) was included to account for the uncertainty associated to the computation of metrics used as response variables in the appropriate model.

To gather insights into occurring community composition changes, we analyzed the effect of shifting composition metrics as well as functional groups on the total abundance of macroinvertebrates over time (GLMM). This approach could indicate not only which group increases or decreases in relation to changing temperatures through time, but also reveal which changing group has the highest magnitude on the community composition. In every utilized model, we included as many 
Table 2 Selected metrics and their association within community describing metric groups

\begin{tabular}{|c|c|c|c|}
\hline Metric group & Metric & Explanation & Reference \\
\hline \multirow[t]{13}{*}{ Composition/Abundance } & Total abundance & \multicolumn{2}{|l|}{$\begin{array}{l}\text { Describes the total number of all sampled } \\
\text { species abundances }\end{array}$} \\
\hline & $\begin{array}{l}\text { Ephemeroptera, Plecoptera, Trichop- } \\
\text { tera \% }\end{array}$ & $\begin{array}{l}\text { Combined percentage of Plecoptera, } \\
\text { Ephemeroptera and Trichoptera }\end{array}$ & Barbour et al. [5] \\
\hline & EPTCBO \% & $\begin{array}{l}\text { Combined percentage of Plecoptera, } \\
\text { Ephemeroptera, Trichoptera, Coleop- } \\
\text { tera, Bivalvia and Odonate. }\end{array}$ & Lorenz et al. [46] \\
\hline & Plecoptera \% & $\begin{array}{l}\text { Percental contribution of Plecoptera to } \\
\text { overall sample }\end{array}$ & Hering et al. [36] \\
\hline & Trichoptera \% & $\begin{array}{l}\text { Percental contribution of Trichoptera to } \\
\text { overall sample }\end{array}$ & Hering et al. [36] \\
\hline & Ephemeroptera \% & \multicolumn{2}{|c|}{$\begin{array}{l}\text { Percental contribution of Ephemeroptera Hering et al. [36] } \\
\text { to overall sample }\end{array}$} \\
\hline & Coleoptera \% & $\begin{array}{l}\text { Percental contribution of Coleoptera to } \\
\text { overall sample }\end{array}$ & Hering et al. [36] \\
\hline & Bivalvia \% & $\begin{array}{l}\text { Percental contribution of Bivalvia to } \\
\text { overall sample }\end{array}$ & Hering et al. [36] \\
\hline & Odonata \% & $\begin{array}{l}\text { Percental contribution of Odonata to } \\
\text { overall sample }\end{array}$ & Hering et al. [36] \\
\hline & Hirudinea \% & $\begin{array}{l}\text { Percental contribution of Hirudinea to } \\
\text { overall sample }\end{array}$ & Hering et al. [36] \\
\hline & Gastropoda \% & $\begin{array}{l}\text { Percental contribution of Gastropoda to } \\
\text { overall sample }\end{array}$ & Hering et al. [36] \\
\hline & Diptera \% & $\begin{array}{l}\text { Percental contribution of Diptera to } \\
\text { overall sample }\end{array}$ & Hering et al. [36] \\
\hline & Crustacea \% & $\begin{array}{l}\text { Percental contribution of Crustacean to } \\
\text { overall sample }\end{array}$ & Hering et al. [36] \\
\hline \multirow[t]{6}{*}{ Richness/Diversity } & Number of Taxa & \multicolumn{2}{|l|}{ Total number of taxa present in a sample } \\
\hline & Number of Families & \multicolumn{2}{|l|}{$\begin{array}{l}\text { Total number of Families present in a } \\
\text { sample }\end{array}$} \\
\hline & Shannon-Wiener & Indicator of species diversity & Shannon and Weaver [65] \\
\hline & Simpson Diversity & Indicator of species diversity & Simpson [67] \\
\hline & Margalef richness & Indicator of species richness & Margalef [47] \\
\hline & Evenness & \multicolumn{2}{|l|}{$\begin{array}{l}\text { Indicator referring to balanced species } \\
\text { abundances }\end{array}$} \\
\hline \multirow[t]{6}{*}{ Tolerance/Sensitivity } & German Saprobic Index & $\begin{array}{l}\text { Indication or measure of the level of } \\
\text { organic pollution }\end{array}$ & Rolauffs et al. [59] \\
\hline & Saprobic index_-Zelinka and Marvan & $\begin{array}{l}\text { Indication or measure of the level of } \\
\text { organic pollution }\end{array}$ & Zelinka and Marvan [75] \\
\hline & BMWP Score & $\begin{array}{l}\text { Measure of water quality according to } \\
\text { aquatic invertebrate tolerance to pol- } \\
\text { lutants }\end{array}$ & Hawkes [35] \\
\hline & Average Score per Taxon & $\begin{array}{l}\text { Average of the tolerance scores of all } \\
\text { macroinvertebrate families found in a } \\
\text { sample }\end{array}$ & Hawkes [35] \\
\hline & Index of biocoenotic region & $\begin{array}{l}\text { Index describing the distribution of mac- } \\
\text { roinvertebrates in biocoenotic regions }\end{array}$ & Armitage et al. [2] \\
\hline & $\mathrm{CTl}$ & Community Temperature Index & Haase et al. [32] \\
\hline
\end{tabular}


Table 2 (continued)

\begin{tabular}{|c|c|c|c|}
\hline Metric group & Metric & Explanation & Reference \\
\hline \multirow[t]{6}{*}{ Functional groups } & Active filter feeder \% & $\begin{array}{l}\text { Percental contribution of active filter } \\
\text { feeder to overall sample }\end{array}$ & Hering et al. [36] \\
\hline & Passive filter feeder \% & $\begin{array}{l}\text { Percental contribution of passive filter } \\
\text { feeder to overall sample }\end{array}$ & \\
\hline & Gatherers and Collectors \% & $\begin{array}{l}\text { Percental contribution of gatherers and } \\
\text { collectors to overall sample }\end{array}$ & \\
\hline & Grazers and Scrapers \% & $\begin{array}{l}\text { Percental contribution of Grazers and } \\
\text { scrapers to overall sample }\end{array}$ & \\
\hline & Predators \% & $\begin{array}{l}\text { Percental contribution of predators to } \\
\text { overall sample }\end{array}$ & \\
\hline & Shredders \% & $\begin{array}{l}\text { Percental contribution of shredders to } \\
\text { overall sample }\end{array}$ & \\
\hline \multirow[t]{2}{*}{ Others } & Fauna Index & $\begin{array}{l}\text { Descriptor of the macrozoobenthos on } \\
\text { the basis of type-specific indicator } \\
\text { species }\end{array}$ & Lorenz et al. [46] \\
\hline & Multi-Metric Index & $\begin{array}{l}\text { German national metric describing the } \\
\text { general degradation of a site }\end{array}$ & Böhmer et al. [12] \\
\hline
\end{tabular}

variables as possible considering the lack of local site specific variables, finding a good trade-off between data-set size and resolution. Lastly, as a means of evaluation, the slopes of CTI, temperature and quality metrics as well as their $95 \%$ confidence interval were compared using linear mixed-effect models. To enable this assessment, it was ensured that the direction of slopes was identical by eventual inversion of variables.

\section{Supplementary information}

Supplementary information accompanies this paper at https://doi. org/10.1186/s12302-020-00403-9.

Additional file 1. Mean annual temperature in the study area from 1970 to 2018 in $\left[{ }^{\circ} \mathrm{C}\right]$. The red line indicates the increasing temperature trend previous to our studied period and the orange line the trend when considering the last 30 years prior to the last year of our studied period. The blue line indicated the temperature trend from the investigated period (data from https://www.dwd.de/DE/leistungen/zeitreihen/zeitr eihen.html).

Additional file 2. Mean annual precipitation in the study area from 1999 to 2014 in [mm]. The dotted line indicates the trend for the investigated period (data from https://www.dwd.de/DE/leistungen/zeitreihen/zeitr eihen.html).

Additional file 3. Land use types in 2000 compared to land use types in 2012. Values are displayed in percent.

Additional file 4. Study area. Sampling sites are marked as red circles. AT: Austria, DE: Germany, LU: Luxemburg, CZ: Czech Republic, F: France, B: Belgium, NL: Netherlands, and AT: Austria.

\section{Acknowledgements}

We acknowledge the E-OBS dataset from the EU-FP6 project UERRA (http:// www.uerra.eu) and the Copernicus Climate Change Service, and the data providers in the ECA\&D project (https://www.ecad.eu). We thank Ross N. Cuthbert for proofreading and language editing. We also greatly acknowledge the provision of biotic and environmental data by the water authorities of the German federal states of Baden-Württemberg, Hesse, Lower Saxony, Mecklenburg-Vorpommern, North Rhine-Westphalia, Rhineland-Palatinate, Saxony, Saxony-Anhalt, Schleswig-Holstein and Thuringia. We acknowledge the help of Andrea Sundermann for the assembly of land use data utilized in this study. The authors wish to thank all contributors to the freshwaterecology. info database.

\section{Authors' contributions}

$\mathrm{PH}$ perceived the idea; FP, PH and PJH designed the methodology; PJH collected the data; PJH and FP analyzed the data; PH and PJH led the writing of the manuscript. All authors read and approved the final manuscript.

Funding

Open Access funding enabled and organized by Projekt DEAL.

\section{Availability of data and materials}

The dataset generated and analysed during the current study is not publicly available due to data ownership belonging to the acknowledged Germany's state authorities but are available on reasonable request.

\section{Ethics approval and consent to participate}

Not applicable.

\section{Consent for publication}

Not applicable.

\section{Competing interests}

The authors declare that they have no competing interests.

\section{Author details}

${ }^{1}$ Department of River Ecology and Conservation, Senckenberg Research Institute and Natural History Museum Frankfurt, Clamecystrasse 12, 63571 Gelnhausen, Germany. ${ }^{2}$ Environmental Archaeology Lab, Department of Historical, Philosophical and Religious Studies, Umeå University, Umeå, Sweden. ${ }^{3}$ Faculty of Biology, University of Duisburg-Essen, Universitätsstraße 5, 45141 Essen, Germany. ${ }^{4}$ South Bohemian Research Center of Aquaculture and Biodiversity of Hydrocenoses, Faculty of Fisheries and Protection of Waters, University of South Bohemia in České Budějovice, Zátiší 728/II, 389 25 Vodňany, Czech Republic.

Received: 14 May 2020 Accepted: 14 September 2020 Published online: 03 October 2020 


\section{References}

1. Altieri AH, Gedan KB (2015) Climate change and dead zones. Glob Change Biol 21:1395-1406

2. Armitage PD, Moss D, Wright JT, Furse MT (1983) The performance of the new biological water quality score system based on macroinvertebrates over a wide range of unpolluted running watersites. Water Res 17:333-347

3. Arora R, Tockner K, Venohr M (2016) Changing river temperatures in northern Germany: trends and drivers of change. Hydrol Process 30:3084-3096

4. Bálint M, Domisch S, Engelhardt CHM, Haase P, Lehrian S, Sauer J, Nowak C (2011) Cryptic biodiversity loss linked to global climate change. Nat Clim Change 1:313

5. Barbour MT, Gerritsen J, Snyder BD, Stribling JB (1997) Revision to rapid bioassessment protocols for use in streams and rivers. Periphyton, benthic macroinvertebrates and fish

6. Bates D, Maechler M, Bolker B, Walker S (2014) Ime4: Linear mixedeffects models using Eigen and S4. R Package Vers. 1:1-23

7. Bellard C, Bertelsmeier C, Leadley P, Thuiller W, Courchamp F (2012) Impacts of climate change on the future of biodiversity. Ecol Lett 15:365-377

8. Bërzinš B, Pejler B (1989) Rotifer occurrence in relation to oxygen content. Hydrobiologia 183:165-172

9. Birk S, Bonne W, Borja A, Brucet S, Courrat A, Poikane S, Hering D (2012) Three hundred ways to assess Europe's surface waters: an almost complete overview of biological methods to implement the Water Framework Directive. Ecol Ind 18:31-41

10. Blüthgen N, Dormann CF, Prati D, Klaus VH, Kleinebecker T, Hölzel N, Müller J (2012) A quantitative index of land-use intensity in grasslands: integrating mowing, grazing and fertilization. Basic Appl Ecol 13:207-220

11. BMUB/UBA (2016) Die Wasserrahmenrichtlinie-Deutschlands Gewässer 2015. Bonn, Dessau

12. Böhmer J, Rawer-Jost C, Zenker A, Meier C, Feld CK, Biss R, Hering D (2004) Assessing streams in Germany with benthic invertebrates: development of a multimetric invertebrate based assessment system. Limnologica 34(4):416-432

13. Brun A (2015) The "renaturation" of urban rivers: The case of the St Charles River in Quebec. In Understanding and managing urban water in transition, Springer, 527-548

14. Burgmer T, Hillebrand $H$, Pfenninger M (2007) Effects of climate-driven temperature changes on the diversity of freshwater macroinvertebrates. Oecologia 151:93-103

15. Canobbio S, Mezzanotte V, Sanfilippo U, Benvenuto F (2009) Effect of multiple stressors on water quality and macroinvertebrate assemblages in an effluent-dominated stream. Water Air Soil Pollut 198:359-371

16. Chessman BC (2009) Climatic changes and 13-year trends in stream macroinvertebrate assemblages in New South Wales, Australia. Glob Change Biol 15:2791-2802

17. Crisp DT, Howson G (1982) Effect of air temperature upon mean water temperature in streams in the north Pennines and English Lake District. Freshw Biol 12(4):359-367

18. Cornes R, Van der Schrier G, Van den Besselaar EJM, Jones PD (2018) An ensemble version of the E-OBS temperature and precipitation datasets. J Geophys Res Atmos. https://doi.org/10.1029/2017JD028200

19. De Figueroa JT, López-Rodríguez MJ, Lorenz A, GrafW, Schmidt-Kloiber A, Hering D (2010) Vulnerable taxa of European Plecoptera (Insecta) in the context of climate change. Biodivers Conserv 19:1269-1277

20. Devictor $V$, Julliard $R$, Couvet $D$, Jiguet $F$ (2008) Birds are tracking climate warming, but not fast enough. Proceed Royal Soc B Biol Sci 275:2743-2748

21. Devictor V, Van Swaay C, Brereton T, Brotons L, Chamberlain D, Heliölä J, Reif J (2012) Differences in the climatic debts of birds and butterflies at a continental scale. Nat Clim Change 2:121

22. Domisch S, Jaehnig SC, Haase P (2011) Climate-change winners and losers: stream macroinvertebrates of a submontane region in Central Europe. Freshw Biol 56:2009-2020

23. Domisch S, Araújo MB, Bonada N, Pauls SU, Jähnig SC, Haase P (2013) Modelling distribution in European stream macroinvertebrates under future climates. Glob Change Biol 19:752-762
24. Doka SE, Mcnicol DK, Mallory ML, Wong I, Minns CK, Yan ND (2003) Assessing potential for recovery of biotic richness and indicator species due to changes in acidic deposition and lake $\mathrm{pH}$ in five areas of southeastern Canada. Environ Monit Assess 88:53-101

25. Ducharne A (2007) Importance of stream temperature to climate change impact on water quality. Hydrol Earth Syst Sci 12:797-810

26. Easterling DR, Wehner MF (2009) Is the climate warming or cooling?. Geophy Res Lett 36

27. Elston DA, Moss R, Boulinier T, Arrowsmith C, Lambin X (2001) Analysis of aggregation, a worked example: numbers of ticks on red grouse chicks. Parasitology 122:563-569

28. Feio MJ, Poquet JM (2011) Predictive models for freshwater biological assessment: statistical approaches, biological elements and the Iberian Peninsula experience: a review. Int Rev Hydrobiol 96:321-346

29. Friedland KD, Hare JA (2007) Long-term trends and regime shifts in sea surface temperature on the continental shelf of the northeast United States. Cont Shelf Res 27(18):2313-2328

30. Haase $P$, Lohse $S$, Pauls $S$, Schindehütte $K$, Sundermann A, Rolauffs $P$, Hering D (2004) Assessing streams in Germany with benthic invertebrates: development of a practical standardised protocol for macroinvertebrate sampling and sorting. Limnologica 34:349-365

31. Haase P, Murray-Bligh J, Lohse S, Pauls S, Sundermann A, Gunn R, Clarke R (2006) Assessing the impact of errors in sorting and identifying macroinvertebrate samples. Hydrobiologia 566:505-521

32. Haase P, Pilotto F, Li F, Sundermann A, Lorenz AW, Tonkin JD, Stoll S (2019) Moderate warming over the past 25 years has already reorganized stream invertebrate communities. Sci Total Environ 658:1531-1538

33. Haidekker A. (2005) The effect of water temperature regime on benthic macroinvertebrates: A contribution to the ecological assessment of rivers (Doctoral dissertation, Duisburg-Essen, 2005)

34. Haidekker A, Hering D (2008) Relationship between benthic insects (Ephemeroptera, Plecoptera, Coleoptera, Trichoptera) and temperature in small and medium-sized streams in Germany: a multivariate study. Aquat Ecol 42:463-481

35. Hawkes HA (1998) Origin and development of the biological monitoring working party score system. Water Res 32:964-968

36. Hering D, Meier C, Rawer-Jost C, Feld CK, Biss R, Zenker A, Böhmer J (2004) Assessing streams in Germany with benthic invertebrates: selection of candidate metrics. Limnologica 34:398-415

37. Hering D, Moog O, Sandin L, Verdonschot PF (2004) Overview and application of the AQEM assessment system. Hydrobiologia 516:1-20

38. Hering D, Haidekker A, Schmidt-Kloiber A, Barker T, Buisson L, Graf W, Stendera S. (2010) Monitoring the responses of freshwater ecosystems to climate change. Clim Change Impacts Freshwater Ecosyst, 84-118

39. Hering D, Schmidt-Kloiber A, Murphy J, Lücke S, Zamora-Munoz C, LópezRodríguez MJ, GrafW (2009) Potential impact of climate change on aquatic insects: a sensitivity analysis for European caddisflies (Trichoptera) based on distribution patterns and ecological preferences. Aquat Sci 71:3-14

40. Jourdan J, O'Hara RB, Bottarin R, Huttunen KL, Kuemmerlen M, Monteith D, Springe $G$ (2018) Effects of changing climate on European stream invertebrate communities: a long-term data analysis. Sci Total Environ 621:588-599

41. Jourdan J, Plath M, Tonkin JD, Ceylan M, Dumeier AC, Gellert G, Matthae CD (2019) Reintroduction of freshwater macroinvertebrates: challenges and opportunities. Biol Rev 94:368-387

42. Jyväsjärvi J, Hämäläinen H (2015) Profundal benthic invertebrate communities in boreal lakes vary with climate fluctuation. Aquat Sci 77:261-269

43. Lavoie D, Denman KL, Macdonald RW (2010) Effects of future climate change on primary productivity and export fluxes in the Beaufort Sea. J Geophy Res Oceans 115

44. Leps M, Tonkin JD, Dahm V, Haase P, Sundermann A (2015) Disentangling environmental drivers of benthic invertebrate assemblages: the role of spatial scale and riverscape heterogeneity in a multiple stressor environment. Sci Total Environ 536:546-556

45. Lopes-Lima M, Teixeira A, Froufe E, Lopes A, Varandas S, Sousa R (2014) Biology and conservation of freshwater bivalves: past, present and future perspectives. Hydrobiologia 735:1-13

46. Lorenz A, Hering D, Feld CK, Rolauffs P (2004) A new method for assessing the impact of hydromorphological degradation on the macroinvertebrate fauna of five German stream types. Hydrobiologia 516:107-127 
47. Margalef R (1958) Information theory in ecology. Gen Syste 3:36-71

48. Mbow HOP, Reisinger A, Canadell J, O'Brien P (2017) Special Report on climate change, desertification, land degradation, sustainable land management, food security, and greenhouse gas fluxes in terrestrial ecosystems (SR2)

49. Meier C, Böhmer J, Biss R, Feld C, Haase P, Lorenz A, Sundermann A (2006) Weiterentwicklung und Anpassung des nationalen Bewertungssystems für Makrozoobenthos an neue internationale Vorgaben. University of Duisburg-Essen, Essen (Förderkennzeichen (UFOPLAN) 20224 223)

50. Mimikou MA, Baltas E, Varanou E, Pantazis K (2000) Regional impacts of climate change on water resources quantity and quality indicators. J Hydrol 234:95-109

51. Murphy JM, Sexton DMH, Jenkins GJ, Boorman PM, Booth B, Brown C, Betts RA (2009) UK climate projections science report: climate change projections. Met Office Hadley Centre, Exeter 21-35

52. OfenböckT, Moog O, Gerritsen J, Barbour M (2004) A stressor specific multimetric approach for monitoring running waters in Austria using benthic macro-invertebrates. In Integrated Assessment of Running Waters in Europe (pp. 251-268). Springer, Dordrecht

53. Paisley MF, Trigg DJ, Walley WJ (2014) Revision of the biological monitoring working party (bmwp) score system: derivation of present-only and abundance-related scores from field data. River Res Appl 30:887-904

54. Pinheiro J, Bates D, DebRoy S, Sarkar D (2017) R Core Team (2017) nlme: linear and nonlinear mixed effects models. R package version 3.1-131. Computer software] Retrieved from https://CRAN.R-project.org/packa ge $=$ nlme

55. Post E, Forchhammer MC, Bret-Harte MS, Callaghan TV, Christensen TR, Elberling B, Ims RA (2009) Ecological dynamics across the Arctic associated with recent climate change. Science 325:1355-1358

56. Pottgiesser T, Sommerhäuser M (2014) Fließgewässertypologie Deutschlands. Handbuch Angewandte Limnologie: Grundlagen-Gewässerbelastung-Restaurierung-Aquatische Ökotoxikologie-Bewertung-Gewässerschutz, 1:61

57. Rabeni CF, Wang N (2001) Bioassessment of streams using macroinvertebrates: are the Chironomidae necessary? Environ Monit Assess 71:177-185

58. Rodríguez-Sánchez F, De Frenne P, Hampe A (2012) Uncertainty in thermal tolerances and climatic debt. Nat Clim Change 2:636

59. Rolauffs P, Stubauer I, Moog O, Zahrádková S, Brabec K (2004) Integration of the saprobic system into the European Union Water Framework Directive. In Integrated Assessment of Running Waters in Europe. (pp.285298). Springer, Dordrecht

60. Rutherford JC, Blackett S, Blackett C, Saito L, Davies-Colley RJ (1997) Predicting the effects of shade on water temperature in small streams. NZ J Mar Freshwat Res 31:707-721
61. Sandin L, Hering D (2004). Comparing macroinvertebrate indices to detect organic pollution across Europe: a contribution to the EC Water Framework Directive intercalibration. In Integrated Assessment of Running Waters in Europe (pp.55-68). Springer, Dordrecht

62. Sauer J, Domisch S, Nowak C, Haase P (2011) Low mountain ranges: summit traps for montane freshwater species under climate change. Biodivers Conserv 20:3133-3146

63. Schmidt-Kloiber A, Hering D (2015) www.freshwaterecology.info-An online tool that unifies, standardizes and codifies more than 20,000 European freshwater organisms and their ecological preferences. Ecol Ind 53:271-282

64. Scrine J, Jochum M, Ólafsson JS, O'Gorman EJ (2017) Interactive effects of temperature and habitat complexity on freshwater communities. Ecol Evol 7(22):9333-9346

65. Shannon CE, Weaver W (1949) The mathematical theory of communication. University of Illinois Press, Urbana

66. Simon HA (1954) Spurious correlation: a causal interpretation. J Am Stat Assoc 49:467-479

67. Simpson EH (1949) Measurement of diversity. Nature 163:688-688

68. Stewart KW (2009) Plecoptera: Stoneflies. In Encyclopedia of Insects (pp.810-813). Academic Press

69. Tania M, Mihăiescu R (2009) European Union Water Framework Directive. ProEnvironment 2:55-57

70. Tayleur CM, Devictor V, Gaüzère P, Jonzén N, Smith HG, Lindström Å (2016) Regional variation in climate change winners and losers highlights the rapid loss of cold-dwelling species. Divers Distrib 22:468-480

71. Vasseur DA, DeLong JP, Gilbert B, Greig HS, Harley CD, McCann KS, O'Connor MI (2014) Increased temperature variation poses a greater risk to species than climate warming. Proceedings of the Royal Society B: Biological Sciences 281

72. Vaughan IP, Gotelli NJ (2019) Water quality improvements offset the climatic debt for stream macroinvertebrates over twenty years. Nat Commun 10:1-8

73. Walther GR (2010) Community and ecosystem responses to recent climate change. Philoso Transact Royal Soc B Biol Sci 365:2019-2024

74. Whiles MR, Dodds WK (2002) Relationships between stream size, suspended particles, and filter-feeding macroinvertebrates in a Great Plains drainage network. J Environ Qual 31:1589-1600

75. Zelinka M, Marvan P (1961) Zur prazisierung der biologischen klassifikation der reinheit fliessender gewasser./4rc

\section{Publisher's Note}

Springer Nature remains neutral with regard to jurisdictional claims in published maps and institutional affiliations.

\section{Submit your manuscript to a SpringerOpen ${ }^{\circ}$ journal and benefit from:}

- Convenient online submission

- Rigorous peer review

- Open access: articles freely available online

- High visibility within the field

Retaining the copyright to your article

Submit your next manuscript at springeropen.com 